\title{
THE DALKON SHIELD CLAIMANTS TRUST
}

\author{
KenNeth R. FeinberG*
}

INTRODUCTION

Mass tort cases, involving hundreds or thousands of injured plaintiffs, multiple defendants, and complex scientific and technical issues, present unique and complex problems for both courts and litigants. From the defendants' point of view, mass tort litigation raises the specter of protracted and costly proceedings with the potential for devastating financial loss. For plaintiffs, mass tort litigation offers the potential for seemingly endless years of legal maneuvering in the quest to obtain compensation for serious and disabling injuries. There is widespread agreement among attorneys, judges, and policymakers that the proliferation of certain mass tort controversies in recent years has severely stressed and overburdened judicial resources.

Some courts and litigants have sought to address the problems engendered by mass tort litigation by developing methods to settle the mass of claims in the aggregate and thereafter implementing administrative procedures for distributing compensation to individuals. This type of approach was used effectively to resolve two of the largest mass tort controversies to arise-the Agent Orange Product Liability Litigation ${ }^{1}$ and the Dalkon Shield personal injury cases. ${ }^{2}$

The purpose of this article is to examine such methods of resolving mass tort litigation. It is intended as a road map of issues that must be considered in attempting an aggregate settlement of a mass tort litigation and in developing a viable, efficient administrative system for delivering compensation.

The remainder of the article is divided into three sections. The first section discusses the issues involved in attempting a comprehensive, aggregate settlement in the mass tort context. The second section examines the development of a mechanism for distributing funds to individual plaintiffs. The article concludes with a case history of the Dalkon Shield litigation, which provides an illustrative example of the issues involved in aggregating claims

\footnotetext{
Copyright () 1990 by Law and Contemporary Problems

* Partner in the law firm of Kaye, Scholer, Fierman, Hays \& Handler. The author is a former trustee for the Dalkon Shield Claimants Trust and is the court-appointed special master in the Agent Orange product liability litigation.

1. In re "Agent Orange" Product Liability Litigation, 611 F Supp 1396 (ED NY 1985); 597 F Supp 740 (ED NY 1984), aff'd, 818 F2d 14 (2d Cir 1987). See also Harvey P. Berman, The Agent Orange Veteran Payment Program, 53 L \& Contemp Probs 49 (Autumn 1990).

2. In re A.H. Robins, 788 F2d 994 (4th Cir 1986); 880 F2d 694 (4th Cir 1989).
} 
and of various options for distributing compensation through an administrative mechanism.

In each of these areas, the intent of this article is to raise the various issues that will arise in attempting an aggregate settlement of a mass tort controversy and, where appropriate, to offer some options that might be considered in addressing these issues. Although each case will present new and unique issues, it is hoped that this article will help guide parties who find themselves embroiled in such a controversy to a fair and effective resolution of the matter.

\section{II}

\section{Settlement: Achieving Aggregate Resolution of a Mass Tort}

The high costs and financial risks associated with case-by-case litigation of thousands of claims provide powerful incentives to seek alternative means of resolving a mass tort controversy. Yet the very nature of mass tort litigation, with hundreds of parties spread over a variety of jurisdictions, makes it extraordinarily difficult to achieve a comprehensive resolution involving all parties. This section of the article will analyze the issues involved in reaching a comprehensive settlement of a "typical" mass tort litigation, ${ }^{3}$ starting with a brief overview of the problems of mass tort litigation and concluding with issues of concern in developing a settlement agreement or resolution plan.

A. The Problems of Mass Tort Litigation: Incentives to Settle

1. High Litigation Costs. The financial costs of resolving mass tort controversies, particularly those involving claims of injury or disease due to exposure to a "toxic" substance, through the traditional tort system can be massive. Mass tort litigation often involves complex technical and legal issues that require analysis by numerous (costly) experts. The multiplicity of parties engenders protracted and duplicative legal proceedings, which increases the already high litigation costs.

In the Agent Orange litigation, one of the largest class action toxic tort cases ever brought, the parties estimated that the initial trial could last as long as eighteen months, and that subsequent appeals and other proceedings might last as long as a decade. ${ }^{4}$

3. The term "mass tort litigation" is used to describe a variety of types of tort claims ranging from a single accident involving numerous victims, such as an airplane crash, to a controversy involving widespread exposure to a harmful product. Some of the concepts and issues discussed in this article are most applicable to the category of mass tort known as "toxic torts," involving claims that exposure to a product has produced widespread injury.

4. See Peter H. Schuck, Agent Orange On Trial 5 (Harvard U Press, 1986). The discovery costs alone in the Agent Orange case were astounding:

[I]n the Agent Orange litigation, solely with respect to the government contract defense, the defendants took more than 200 depositions of former or current government employees. Assume that the depositions were performed by outside counsel and that each deposition took two days. Assume that the defendants' counsel each spent one day preparing for each deposition and another day summarizing and reviewing. Assume that the law firms used teams of two attorneys with an hourly billing rate for each attorney of $\$ 150$. The calculation 
In fact, the cost of litigating "mass" tort claims can exceed the amount eventually paid in damages to plaintiffs. One study of asbestos litigation, for example, estimated that plaintiffs on the average receive only 37 percent of the litigation expenses incurred by defendants and their insurers, which means that almost two-thirds of the total amount spent is relegated to attorneys' fees and other litigation expenses. ${ }^{5}$ Such litigation expense-topayout ratios are obviously undesirable for both litigants and society; from all points-of-view, it is most desirable to provide appropriate compensation to the victim with a minimum of transactional costs.

2. Indirect Costs/Loss of Productivity. In addition to the direct costs of litigation, parties and litigants in mass tort controversies incur a variety of indirect costs. For defendants (generally corporate entities), indirect costs include the loss in productivity that results from the diversion of resources from production to the defense of litigation and the loss of goodwill that can result from adverse media attention. The threat of uncertain future liability can increase the cost of doing business by inflating insurance premiums, depressing stock prices, and raising credit terms.

For plaintiffs, mass tort litigation imposes undesirable personal costs. Individuals suffering from serious or fatal diseases desperately need financial assistance. But the complexities of the litigation and the defendants' tendency to employ aggressive litigation strategies so as to minimize a potentially devastating financial situation can lead to significant delays in the final resolution of plaintiffs' claims. The proliferation of asbestos personal injury cases, which has outstripped the ability of the courts and the parties to dispose of cases, inevitably will lead to further delays. ${ }^{6}$

3. Large and Uncertain Liabilities. For all parties, mass tort litigation presents extraordinary risks. Defendants confront the possibility of devastating financial loss if hundreds or thousands of plaintiffs recover large compensatory damage awards. ${ }^{7}$ Plaintiffs risk the possibility of little or no compensation after years of burdensome legal proceedings and emotional strain.

begins with: 200 depositions $x 4$ days $x 8$ hours $=6400$ hours. The next step is 6400 hours $x 14$ attorneys (2 for each defendant) $x \$ 150$ per hour $=$ a total cost for attorneys of $\$ 13,440,000$ for deposition costs for this aspect of the suit, leaving out transcript fees, travel costs, and other expenses. This cost would be multiplied several times over in the taking of depositions of the plaintiffs, the defendants, their physicians and expert witnesses.

Robert H. Sand, How Much Is Enough? Observations in Light of the Agent Orange Settlement, 9 Harv Envir L. Rev 283, 297-98 (1985).

5. James S. Kakalik, et al, Costs of Asbestos Litigation 40 (RAND, 1983).

6. See Order to Show Cause, In re Asbestos Products Liability Litigation, No. 875, n3. (Judicial Panel on MultiDistrict Litigation, January 17, 1991) (Number VI).

7. The number of companies that have declared bankruptcy in the face of soaring tort claims, including the A.H. Robins Company (manufacturer of the Dalkon Shield) and the Manville Corporation (manufacturer of asbestos-containing products), illustrates the enormous risks faced by defendants in mass tort controversies. See generally, Kane v Johns-Manville Corp., 843 F2d 636 (2d Cir 1988). 
For all parties, mass tort litigation is fraught with uncertainty. In a mass toxic tort case involving widespread exposure to a harmful product, defendants are often unable to predict the total potential liability. The number of persons exposed to the product who will suffer an injury and file a claim may be impossible to determine. For plaintiffs, there is great uncertainty about both the length of time that litigation of their claims will consume, and the amount of money that may ultimately be available for recovery from defendants.

4. Complex Legal and Scientific Issues. The burdens of mass tort litigation are compounded in toxic tort cases by the complexities of the scientific issues involved. Plaintiffs in such cases have traditionally faced extraordinary difficulties in establishing a causal connection between the harmful product and the particular injury. Scientific evidence that may provide the basis for medical diagnoses or epidemiological studies is often not transferrable to the legal system. Even where a plaintiff is able to establish general causation, that is, an accepted causal relationship between a particular product and certain types of diseases, the plaintiff may be unable to show that his or her disease was caused by the product at issue and not some other agent. ${ }^{8}$ The difficulty in establishing causation is magnified where there is a long latency period between the exposure to a product and the development of the disease. As the length of time between exposure and development of the disease increases, the likelihood that the plaintiff's exposure to other agents that might have caused the same disease also increases. ${ }^{9}$ In addition, a long latency period exacerbates problems of identifying the particular product that caused the injury.

5. Demands on the Justice System. Mass tort litigation imposes undesirable burdens on the courts and society as a whole. Litigation of mass tort controversies involving hundreds or thousands of claims in a single forum or proceeding severely stresses traditional legal procedures and conventions. The sheer number of parties alone can make even the most routine pretrial discovery proceeding or motion hearing exceedingly burdensome, and often ties up judicial resources to the detriment of litigants in other cases.

Moreover, and perhaps more importantly, existing legal conventions create undesirable incentives for the parties involved in mass tort controversies and threaten to undermine traditional precepts of fairness and

8. The mere possibility of a particular product causing the defendant's disease is not enough. A direct, or proximate, causal relationship between the defendant's product and the plaintiff's disease must be established. The plaintiff, therefore, must "introduce evidence which affords a reasonable basis for the conclusion that it is more likely than not that the conduct of the defendant was a substantial factor in bringing about" the defendant's illness. William Lloyd Prosser, Handbook of the Law of Torts, 41, 241 (West, 4th ed 1971) (emphasis added).

9. See generally Sheila B. Birnbaum, Tort Damages for Fear and Risk of Injury, 31 Prac Law 25 (1985); Lawrence B. Novey, Collective Judicial Management of Mass Toxic Tort Controversies: Lessons and Issues from the Agent Orange Litigation, $27 \mathrm{~J}$ Soc Sci \& Med 1071 (1988); Aaron A. Twerski, With Liberty and Justice for All: An Essay on Agent Orange and Choice of Law, 52 Brooklyn L Rev 341 (1986); Paul Sherman, Agent Orange and the Problems of the Indeterminate Plaintiff, 52 Brooklyn L Rev 369 (1986). 
equity on which our judicial system is based. The risks involved in mass tort cases encourage the parties to engage in duplicative and aggressive litigation of each issue, thus increasing the burden on the courts and the cost to litigants. Increasing costs can affect the parties in disparate ways and may lead to a final determination of the matter based principally on the parties' relative abilities to pay attorneys' and other fees (or the plaintiffs' attorneys willingness to undertake and finance such litigation) rather than on the merits of the case. In addition, the distribution of individual cases over several jurisdictions can lead to dramatically different results in essentially similar cases. ${ }^{10}$ This in turn may lead plaintiffs and defendants to utilize available procedures to file, transfer, or remove cases to the most favorable forum, thus increasing the burdens on those judicial facilities.

6. Criticisms of the Tort System-Pursuing Alternatives. The use of the existing tort system to resolve mass tort controversies on a case-by-case basis has been heavily criticized. Commentators and litigants have argued that the process is too slow, too costly, and too erratic. " system creates undesirable incentives for both plaintiffs and defendants. ${ }^{12}$ Contingent fee awards and the high costs of litigation encourage plaintiffs' attorneys to file large numbers of cases, even if some claims are relatively weak, in the hope of obtaining a package settlement. Defendants, who generally have greater financial resources than plaintiffs or their attorneys, may be better able to maintain an aggressive litigation posture and may simply wear out the plaintiffs. Our legal conventions can also create inequities. The judicial treatment of scientific evidence may deny compensation to true victims of a harmful product, and the litigation of individual claims at different times in different places with different juries and different evidentiary rulings will result in inconsistent verdicts and settlements.

These criticisms of the tort system have instigated a variety of proposals to improve the management of mass tort controversies. Such proposals have included development of legislative schemes designed to provide compensation to victims through administrative mechanisms, "tort reform" legislation, creation of specialized federal "national disaster" courts, and development of methods to enhance the power of the courts. ${ }^{13}$ To date, however, no proposal for widescale modification of the current system of

10. See, for example, In re School Asbestos Litigation, 789 F2d 996, 1001 (3rd Cir 1986) (Inconsistencies in verdicts make litigation look "more like roulette than jurisprudence."). See also Comments of Judge Jack B. Weinstein, 5 Toxics L Rptr 1107 (February 6, 1991) (Litigation of asbestos personal injury cases "take on aspects of a lottery.").

11. See generally Institute for Health Policy Analysis, Causation and Financial Compensation for Claims of Personal Injury from Toxic Chemical Exposure (Inst Health Pol'y Analysis, Georgetown U Med Ctr, 1986) (Final Report of the Conference Panel, Lawrence B. Novey, reporter).

12. Id.

13. See generally Jack B. Weinstein, Preliminary Reflections on the Law's Reaction to Disasters, 11 Colum J Envir L 1 (1986). 
determining liability and delivering compensation in the mass tort context has been adopted.

At the same time, the financial and political costs, extraordinary risks, and difficulty of mass tort litigation furnish powerful incentives for both the litigants and the courts involved to seek a comprehensive resolution of the matter outside the traditional litigation mode, for example, through settlement. ${ }^{14}$ In the absence of any viable alternative, parties involved in mass tort controversies have sought to develop innovative methods to resolve such cases in the aggregate. As noted above, in two of the largest mass tort controversies to arise, the Agent Orange Product Liability Litigation and the Dalkon Shield personal injury cases, the parties and courts developed methods of settling the mass of claims in the aggregate and then established administrative mechanisms for distributing funds to individual claimants. ${ }^{15}$

The remainder of this section of the article discusses issues involved in consolidating claims to make a comprehensive resolution possible and factors to consider in developing an aggregate settlement.

\section{B. Achieving a Comprehensive Settlement: Prerequisites to a Settlement}

There are three key prerequisites to a comprehensive and final resolution of a mass tort case: (1) aggregation of claims (both present and potential future); (2) determination of the aggregate liability; and (3) allocation of responsibility among multiple defendants. Once the parties reach agreement on these central issues, they should be able to forge a satisfactory and workable settlement agreement.

1. Aggregative Procedures. In order to achieve a comprehensive resolution of all claims arising out of a particular mass tort situation (whether through litigation or through settlement), the cases must be consolidated. Several

14. Depending on the posture of the cases and the particular factual situation, the parties may view settlement as a risky alternative despite the problems inherent in litigation. From the defendant's perspective, for example, a settlement that does not achieve a comprehensive resolution of all pending and future claims is risky because it may encourage additional claims and set precedents for recovery in other cases arising from the same mass tort. Thus, if the particular mass tort has not yet reached a stage where the bulk of claims has been filed or at least identified, settlement may not be attractive to defendants. Defendants considering settlement of mass tort litigation must also consider the potential impact on insurance coverage. Insurance carriers may contest the insureds' determination that a settlement is desirable, particularly where legal issues such as scientific causation arguably make a finding of liability unlikely. Insurance coverage disputes might also arise in the context of a settlement, particularly when relevant issues such as time and type of injury or the liability of codefendants have not been resolved in the litigation process.

From the plaintiffs' point of view, the risks associated with settlement are more straightforward. Quite simply, in determining whether to settle, the plaintiffs must weigh the amount of recovery that could be obtained through settlement against the costs of and likely recovery that will be obtained through litigation. If there is no previous litigation experience on which to assess settlement offers, settling plaintiffs face the potential for a significantly lower, albeit speedier recovery.

15. See, for example, In re "Agent Orange" Product Liability Litigation, 611 F Supp 1396 (ED NY 1985). The Dalkon Shield case is discussed in detail in Part IV. 
techniques are available to centralize mass tort litigation, and the degree of centralization will vary depending upon the technique used. ${ }^{16}$

a. Multi-district litigation procedure. Pretrial proceedings of cases pending in several federal district courts can be coordinated under the direction of the Judicial Panel on Multi-District Litigation, pursuant to the U.S. Code. ${ }^{17}$ This multi-district litigation procedure, which provides for the transfer of cases from all federal courts to one federal judge for control of preliminary motions, discovery, and settlement, has proven useful in several cases. ${ }^{18}$ In the Agent Orange case, for example, hundreds of cases filed by Vietnam veterans claiming injury as a result of exposure to "Agent Orange" and other herbicides during the Vietnam War were consolidated through multi-district litigation rules in one federal district court. ${ }^{19}$ This technique is limited, however, to cases in federal courts, although some state laws permit consolidation of cases pending within the state. ${ }^{20}$

b. The class action as a consolidation device. A potentially more comprehensive method of consolidating mass tort litigation is the class action device. $^{21}$ Rule 23 of the Federal Rules of Civil Procedure governs the certification of class actions in the federal courts. Under Rule 23, an action may be certified as a class action only if the members of the proposed class meet specific requirements involving (1) numerosity of parties; (2) commonality of legal and factual issues; (3) typicality of the claims and defenses of the class representative; and (4) adequacy of representation. Assuming these requirements are satisfied, the action must meet additional

16. See generally Mark A. Peterson \& Molly Selvin, Resolution of Mass Torts: Toward a Framework for Evaluation of Aggregative Procedures (RAND, 1988) ("Resolution of Mass Torts"); Roger H. Transgrud, Joinder Alternatives in Mass Tort Litigation, 70 Cornell L Rev 779 (1985).

17. 42 USC \& 1407 (a) (1982)

18. Weinstein, 11 Colum J Envir L at $22 \mathrm{n} 57$ (cited in note 13). This consolidation technique was used with only limited success by district courts handling a multiplicity of early suits involving injury from use of the Dalkon Shield. See In re A. H. Robins Co., 880 F2d 709, 712 (4th Cir 1989).

19. In re "Agent Orange" Product Liability Litigation, 800 F2d 1415 (2d Cir 1986).

20. See, for example, Md Circuit Ct R Civ Proc 2-503 (Michie, 1991); Cal Civ Proc Code $\S \S 404.1-404.8$ (West, 1989). U.S. District Court Judge Jack B. Weinstein has suggested that Congress should consider legislation that would allow transfer of both federal and state cases to a single state forum. Weinstein, 11 Colum J Envir L at 24 (cited in note 13). See also Am Bar Ass'n Commission on Mass Torts, Report and Recommendations (ABA, 1989). Multi-district litigation bills were introduced in the United States House of Representatives in both the Spring and Fall of 1989 but were not passed. HR 3152, 100th Cong, lst Sess (1989); HR 3406, 101st Cong, 2d Sess (1989).

21. Unlike multi-district litigation consolidations, the class action device can embrace both actions that have been filed and claims of persons who might manifest injury in the future. For indepth discussion of the strengths and weaknesses of class actions in mass tort settings, see Linda $S$. Mullenix, Class Resolution of the Mass-Tort Case: A Proposed Federal Procedure Act, 64 Tex L Rev 1039 (1986); Novey, $27 \mathrm{~J}$ Soc Sci \& Med 1071 (cited in note 9); Peterson \& Selvin, Resolution of Mass Torts (cited in note 16); Weinstein, 11 Colum J Envir L at 28 (cited in note 13); Spencer Williams, Mass Tort Class Actions: Going, Going, Gone?, reprinted in 98 FRD 323 (1983) (originally presented as a speech to the Multi-District Litigation Panel, Carefree, Arizona, December 9, 1982); Irving R.M. Panzer \& Thomas Earl Patton, Utilizing the Class Actions Device in Mass Tort Litigation, 21 Tort \& Ins L J 560 (1986). 
requirements regarding the fairness and efficiency of the class action procedure as opposed to individual adjudication.

Historically, many courts have rejected attempts to use the class action device in mass tort situations. This reluctance stems in part from the Advisory Committee's Note regarding Rule 23, which states that "mass accident" cases are ordinarily not appropriate for a class action because of the likely presence of significant questions that would affect the individuals in the case in different ways. ${ }^{22}$ In the early stages of the Dalkon Shield litigation, for example, a number of courts denied several attempts to certify a plaintiff class on the ground that individual causation issues made class treatment inappropriate. ${ }^{23}$ Recently, however, courts have begun to recognize the practical advantages of the class action device in handling mass tort controversies. ${ }^{24}$ As one commentator has observed, the reluctance to certify mass tort class actions seems to be fading "in light of what is often an overwhelming need to create an orderly, efficient means for adjudicating hundreds or thousands of related claims."25

Courts that have been receptive to the use of the class action device in mass tort cases have been motivated by both the usefulness of the device in managing the litigation as well as a belief that class certification would facilitate a mass settlement. ${ }^{26}$ In the Agent Orange product liability litigation, for instance, Judge Weinstein certified a class of Vietnam veterans and certain of their family members who sought recovery for injuries suffered as a result of the veterans' exposure to herbicides in Vietnam. ${ }^{27}$ Judge Weinstein noted that "a class-wide finding of causation may serve to resolve the claims of

22. Proposed Amendments to Rules of Civil Procedure for the U.S. District Courts, reprinted in 39 FRD 69, 103 (1966) (Rule 23 advisory committee note). For a comprehensive discussion of the historical evolution of the application of Rule 23, see In re A. H. Robins Co., 880 F2d at 727-47.

23. See Rosenfeld $v$ AH Robins Co, 63 AD2d 11, 407 NYS2d 196 (NY App Div), appeal dismissed, 46 NY2d 731, 413 NYS2d 374, 385 NE2d 1301 (1978) (upholding rejection of class certification because of the problem of individual causality); In re Northern Dist of Cal "Dalkon Shield" IUD Products Liability Litigation, 693 F2d 847 (9th Cir 1982) (vacating district court's certification of a nation-wide class under Rule 23(b)(1)(B) on issue of punitive damages and a state-wide class under Rule 23(b)(3) on issue of liability), cert denied, 459 US 1171 (1983).

24. See for example, In re A. H. Robins Co., 880 F2d at 743; Jenkins v Raymark Indus. Inc., 782 F2d 468, 473 (5th Cir 1986); In re School Asbestos Litigation, 789 F2d 996, 1009 (3d Cir 1986), cert denied, 479 US 852 (1987); In re "Agent Orange" Products Liability Litigation, 100 FRD 718 (ED NY 1983), aff'd, 818 F2d 145 (2d Cir 1987), cert denied, 484 US 1004 (1988).

25. Herbert B. Newberg, Mass Tort Class Actions: Implications of the Johns-Mansville Bankruptcy Action Trial 53 (February 1986).

26. Whether class certification pursuant to Rule 23 is proper solely for the purpose of settlement is the subject of some debate. The only federal court decision that granted class certification strictly for purposes of settlement in a mass tort action, In re Bendectin Product Liability Litigation, 102 FRD 239, 240 (SD Ohio 1984), was invalidated by the Sixth Circuit Court of Appeals, 749 F2d 300 (6th Cir 1984). As noted by the court in that case, however, courts in cases involving numerous parties, although not mass-tort cases, have granted class certification for settlement purposes. See also In re A. H. Robins Co., $880 \mathrm{~F} 2 \mathrm{~d}$ at 740 and cases cited therein ("[I]f not a ground for certification per se, certainly settlement should be a factor, and an important factor to be considered when determining certification.").

27. In re Agent Orange Product Liability Litigation, 100 FRD 718 (ED NY 1983), mandamus denied sub nom In re Diamond Shamrock Chemicals Co., 725 F2d 858 (2d Cir), cert denied, 465 US 1067 (1984). In a later appeal involving the settlement ultimately reached in the Agent Orange case, the Second Circuit Court of Appeals reaffirmed the appropriateness of the class certification but expressed some 
individual members, in a way that determinations in individual cases would not, by enhancing the possibility of settlement among the parties and with the federal government." 28

There are some limitations on the use of the class action to achieve a comprehensive resolution of a mass tort litigation. For example, plaintiffs have the right to opt out of a voluntary class. ${ }^{29}$ Moreover, a court presiding over a class action case is required to approve the settlement. (Case law generally provides that the court must decide whether the settlement is fair, reasonable, and adequate. ${ }^{30}$ ) This determination involves giving notice of the settlement to, and receiving comment from, representative class members. ${ }^{31}$ With thousands of plaintiffs located around the country, some courts might find this requirement overly burdensome.

c. Chapter 11 of the bankruptcy code as a means of centralizing mass tort litigation. A defendant's decision to seek protection under the bankruptcy laws can effectively centralize mass tort litigation. Bankruptcy, of course, is not an option that may be selected by any defendant faced with a mass tort situation. However, an enterprise whose financial survival is threatened by the expense of defending and paying claims arising out of a mass tort (or by other factors) may be able to effect consolidation of the cases after filing for reorganization under chapter 11 of the Bankruptcy Code. ${ }^{32}$ Thus, the defendant may be able to resolve, in one proceeding, the multitude of claims. ${ }^{33}$

concern as to whether the various individual issues might overwhelm the common factors. In re Agent Orange Product Liability Litigation, 818 F2d 145 (2d Cir 1987), cert denied, 108 S Ct 695 (1988).

28. In re Agent Orange Product Liability Litigation, 100 FRD 718. See also In re School Asbestos Litigation, $789 \mathrm{~F} 2 \mathrm{~d}$ at 1009 ("Concentration of individual damage suits in one forum can lead to formidable problems, but the realities of litigation should not be overlooked in theoretical musings. Most tort cases settle, and the preliminary maneuverings in litigation today are designed as much, if not more, for settlement purposes than for trial. Settlements of class actions often result in savings for all concerned."); Bruce H. Nielson, Was the 1966 Advisory Committee Right?: Suggested Revision of Rule 23 to Allow More Frequent Use of Class Actions in Mass Tort Litigation, 25 Harv J Legis 461, 480 (1988) (" $[\mathrm{I}] \mathrm{n}$ recent years, several federal judges have explicitly recognized the effect of class certification on the likelihood of pre-judgment settlement in mass-tort suits, and have apparently allowed such recognition to influence their decision to certify class actions."); Transgrud, 70 Cornell L Rev at 835 (cited in note 16) (class certification as a pretrial joinder device to facilitate group settlements is both proper and desirable).

29. Weinstein, 11 Colum J Envir $\mathrm{L}$ at 28 (cited in note 13) (enumerating limits of the class action device and posing some unresolved questions). Regarding the specific issue of opt-out rights for class members, see In re A. H. Robins Co., $880 \mathrm{~F} 2 \mathrm{~d}$ at 744-45 and sources cited therein.

30. See, for example, West Virginia v Charles Pfizer E Co., 440 F2d 1079, 1085 (2d Cir 1971).

31. See Fed R Civ P 23; In re Agent Orange Product Liability Litigation, 597 F Supp 740, 758-59 (ED NY 1984).

32. 11 USC $\$ \S 1101-1146$ (1982).

33. Pursuant to section 362 of the Bankruptcy Code and the court's general equitable powers, a bankruptcy court has the power to stay all proceedings against the debtor, and in some cases, related actions against co-defendants of the debtor or of third parties. See A. H. Robins Co. v Piccinin, 788 F2d 994, 1002-04 (4th Cir), cert denied, 479 US 876 (1986). A district court sitting in bankruptcy also has the authority to fix the venue of tort cases pending against the debtor and to order, subject to due process notice and opportunity for hearing, that all such cases be tried in the district court in which the bankruptcy case is pending. 28 USC $\$ 157(b)(5)$. The court sitting in bankruptcy therefore has considerable power to centralize mass tort litigation against the debtor into a single forum and to prevent the danger of conflicting judgments in a multiplicity of forums. 
The ultimate goal of a bankruptcy proceeding under chapter 11 is the development of a plan of reorganization that will both rehabilitate the debtor and resolve the claims of creditors, including tort claimants. The bankruptcy court has the power, and the obligation, to estimate a debtor's aggregate liability for personal injury claims in order to determine the feasibility of a reorganization plan. ${ }^{34}$ This estimation of the value of all claims, in addition to the initial centralization of all claims in a single forum, can lead to the establishment of a mechanism for the resolution of claims without the resort to litigation.

Use of the reorganization provisions of chapter 11 to resolve tort liabilities that threaten the financial survival of a corporation is controversial and may not be feasible or practical in many situations. ${ }^{35}$ Moreover, the process does pose some risks for the parties involved in mass tort litigation. From the defendant's perspective, there is the risk that the cloud of uncertainty induced by the bankruptcy process will be more financially harmful than the cloud of tort liabilities that would exist outside of the bankruptcy forum. ${ }^{36}$ For the plaintiff, there is the risk that claims will be undercompensated relative to the potential recovery in court and relative to the claims of other creditors, such as those holding secured claims against the debtor. ${ }^{37}$ In addition, the bankruptcy process may delay the resolution of claims filed before the bankruptcy action began.

Nonetheless, in appropriate circumstances, reorganization under chapter 11 can result in the centralization of mass tort claims, thus facilitating the development of a reasonable plan that will rehabilitate the financial status of an enterprise facing massive tort liability while at the same time assuring fair and consistent resolution of claims. Both the Manville Corporation (an asbestos manufacturer) and the A. H. Robins Company (the manufacturer of the Dalkon Shield) have effectively centralized and resolved mass tort controversies through chapter $11 .{ }^{38}$ The Robins bankruptcy is discussed in detail below.

34. 11 USC $\S 502(\mathrm{c})(1)$. See also 28 USC $\S 157(\mathrm{~b})(2) ; A . H$. Robins Co. v Piccinin, 788 F2d at $1011-12$.

35. See Kaighn Smith, Jr., Beyond the Equity Power of Bankruptcy Courts: Toxic Tort Liabilities in Chapter 11 Cases, 38 Me L Rev 391 (1986) (arguing that use of chapter 11 as forum for resolution of massive tort liabilities is advisable only under limited circumstances-namely, if there is minimal corporate debt relative to tort liability, if uncompensated tort victims outnumber those who obtained compensation before the corporation entered bankruptcy, and if future tort claims will undoubtedly drive the corporation into insolvency-and questioning the power of bankruptcy courts, even under such circumstances, to create a single compensation mechanism for settlement of debtors' present and future obligations to tort victims, absent legislative reform of bankruptcy law); Gregory A. Bibler, The Status of Unaccrued Tort Claims in Chapter 11 Bankruptcy Proceedings, 61 Am Bankr L J 145 (1987) (outlining public policy arguments against use of bankruptcy proceedings for comprehensive resolution of tort liabilities and arguing that toxic tort claims arising from repetition activities of a debtor are not dischargeable in bankruptcy until they have accrued under applicable state nonbankruptcy law).

36. See Smith, $38 \mathrm{Me} \mathrm{L} \mathrm{Rev} \mathrm{at} 445$ (cited in note 35).

37. See Bibler, 61 Am Bankr L J at $147 \mathrm{nl} 3$ (cited in note 35).

38. See Kane v Johns-Manville, 843 F2d 636 (2d Cir 1988); In re A.H. Robins, 88 BR 742 (ED Va 1988). 
2. Determining the Defendants' Liability: Establishing an Aggregate Cap on Liability. Once the mass of claims has been aggregated, litigants seeking a comprehensive and final settlement of all claims must determine an aggregate value of the claims. Deciding on a figure that adequately accounts for all claims-both present and future-in a mass tort controversy is complicated and controversial. In mass toxic tort cases in particular, the universe of potential plaintiffs is often unknown, and the claimants may suffer from a number of different injuries that vary greatly in type and severity. Moreover, the sheer number of parties involved makes a detailed, individualized analysis of the nature and legitimacy of claims difficult, if not impossible.

In the Dalkon Shield controversy, an aggregate settlement value was determined through a comprehensive analysis of a sample of past and pending claims. As discussed more fully below, a profile of pending claims was developed based on questionnaires distributed to claimants, and the aggregate value was determined, in part, by applying historical settlement and litigation results to the pending claims.

Although achieving finality by establishing an aggregate cap on liability is attractive, particularly from the defendants' point of view, in some situations it may be inappropriate or impossible. For example, when the number of future claims is uncertain but potentially greater than existing claims, it may be impossible to determine an aggregate value for the future claims that is reasonable and acceptable to all parties. Similarly, if there are great uncertainties regarding the nature of the claims among the universe of plaintiffs, it may be impossible to determine the aggregate liability. The Manville Corporation, for example, was unable to establish a cap on liability in its bankruptcy plan. Rather, the plan provides for ongoing contributions of assets to the trust established to pay individual claims.

As an alternative to establishing an aggregate value for all claims, present and future, a settlement agreement might simply place a cap on liability for pending claims and establish an open-ended formula that provides for unanticipated future claims. This approach has the disadvantage of leaving all parties with a degree of uncertainty. Plaintiffs might be concerned about securing the defendants' obligations, and defendants will always be hampered by the potential unknown liability. Another alternative might be to establish a formula for individual payments, with certain caps on both individual payments and aggregate payments in any given time period. Indeed, a compensation formula approach is used quite frequently in class actions involving consumer or securities claims.

3. Deciding Who Pays: Allocation Among Defendants. In a case involving multiple defendants, one of the most difficult problems in reaching a comprehensive resolution of the litigation is securing the agreement of all defendants. Without the participation of other defendants in the settlement, a defendant that has settled may face cross-claims and/or claims for contribution or indemnity from jointly liable defendants that could nullify the advantages gained by settling with plaintiffs. 
Once all defendants agree in principle to settle, they must establish some system for allocating responsibility for paying the settlement amount. In each case, the allocation process will differ depending on such factors as the "homogeneity" of the product (that is, whether the harmful product is contained in one product or a variety of products), the geographic distribution of the various defendants' products, the nature of the distribution chain, the presence of a company with a dominant market share, and the availability of historical litigation data.

Defendants in a mass tort controversy may explore a variety of allocation alternatives. In a products liability case, for example, defendants might contribute to a compensation fund on the basis of market share. In many instances, however, selection of the relevant market for determining market share proves to be extraordinarily difficult and controversial. If a product has been distributed widely over a period of years, defendants are likely to contend that each company's market share is different depending on geographic location and the time period at issue. Moreover, if the harmful substance was contained in a variety of different types of products, a market share allocation will be nearly impossible.

Contributions toward the settlement could also be allocated pro rata based on a statistical analysis of the degree of harm caused by each particular defendant. Factors affecting this determination would include not only the defendant's market share but other factors, such as the relative level of toxicity or the degree of defect in each defendant's product. This type of allocation formula might be troublesome because defendants are likely to be reluctant to admit to product defects.

An allocation based on an historical "litigation share" might be appropriate in situations for which such data is available. ${ }^{39}$. While this method on its face might seem uncontroversial, in a mass tort situation, where cases are located in a variety of jurisdictions, selection of the appropriate historical data can be a divisive and difficult task.

Even if the defendants agree on the appropriate historical data, an allocation based on historical litigation share will be successful only if the nature of future claims mirrors claims filed in the past. The "Wellington Agreement," a revolutionary attempt to centralize and resolve the burgeoning number of personal injury cases filed against asbestos companies by pooling assets of defendants and their insurers on the basis of producer shares, failed in part because of changes in the type and source of claims filed. ${ }^{40}$

39. As used in this article, "litigation share" refers to the portion of the overall compensatory award or settlement paid by each defendant on average prior to the consolidated settlement.

40. The asbestos defendants are manufacturers, distributors, and suppliers of a wide variety of types of asbestos containing products, varying from insulation materials to gaskets and rubber products containing some asbestos as well as (in some jurisdictions) contractors that installed products or owners of buildings constructed with the products. While insulation manufacturers might be willing to pay a relatively greater share of compensation to insulation workers, such companies are less willing to pay the same share for claims made by tire workers. The Wellington Agreement included an adjustable producer shares formula based on historical data on the characteristics of claims made. After the agreement was in place, the mix of types of claims changed 


\section{Forging a Settlement}

1. Method of Settlement: Using Non-Binding Mediation as a Settlement Device. The task of achieving agreement among the many parties involved in mass tort litigation will likely require something beyond conventional settlement negotiations and may well require the aid of an outside party to facilitate settlement. Judges have increasingly taken on a more active role in encouraging settlement, sometimes by appointing a special master to facilitate negotiation among parties. ${ }^{41}$ In addition, the parties themselves can seek the aid of an outside party to facilitate negotiation.

Non-binding mediation-a process in which a neutral third party helps the parties arrive at settlement proposals-is a particularly advantageous means of conducting settlement negotiations. ${ }^{42}$ Perhaps the most attractive feature of mediation is its completely voluntary and non-binding nature, which makes participation in the process risk-free. If any party is dissatisfied at any time with any aspect of the proceedings, that party can withdraw and is free to engage in litigation or in other alternative methods of dispute resolution.

The informality and flexibility of the mediation process is another advantage. The parties are free to set their own rules and procedures. Mediation can thus be adapted to a variety of disputes and can be employed at any stage in a dispute, whether or not litigation is already pending. If the discovery stage of litigation has not yet been reached, the parties may choose to incorporate a "mini-discovery" schedule into the mediation process.

The parties' ability to choose the mediator is another advantageous feature of mediation. This ability to select a neutral outside party is particularly useful in complex disputes involving mixed questions of law or fact, where the parties may have more confidence in the mediator's, rather than a jury's, ability to evaluate the case.

All of the above features make non-binding mediation an optimal device for achieving settlement of mass tort litigation. Mediation's completely voluntary and flexible nature allows the parties to explore avenues of settlement without risk. Moreover, even if the mediation process does not succeed in resolving all issues, it may help facilitate certain aspects of the litigation process by encouraging the parties to focus their claims and assess their options realistically. In addition, the mediation process often requires the parties to present factual materials to both their opponents and the mediator. Thus, the process may result in a streamlined and accelerated discovery process.

considerably, according to some defendants, leading to objections and eventual dissolution of the claims facility. See Lawrence Fitzpatrick, The Center for Claims Resolution, 53 L \& Contemp Probs 13 (Autumn 1990).

41. In re "Agent Orange" Product Liability Litigation, 597 F Supp 740, 752-53 (ED NY 1984).

42. For a more detailed explanation of the advantages of mediation as a method of resolving disputes and an outline of a model procedure for mediation, see Kenneth $\mathrm{R}$. Feinberg, Mediation- $A$ Preferred Method of Dispute Resolution, 16 Pepperdine L Rev S5 (1989). 
2. Fashioning a Settlement Agreement. Once the parties have engaged in the settlement process, they still face the issue of fashioning acceptable settlement terms. One common difficulty that can derail settlement negotiations is the parties' tendency to attempt to resolve in the settlement agreement all issues involved in delivering compensation to the individual plaintiffs. Attempting to finalize all such details makes settlement nearly impossible.

The parties are more likely to achieve a comprehensive settlement by focusing on the aggregate issues, such as the size, composition, and source of the compensation fund. Although in many cases the parties will need to prescribe general compensation guidelines in order to determine the aggregate value of the claims, ${ }^{43}$ the settlement agreement need not and probably should not attempt to establish individual settlement amounts for plaintiffs. Rather, the settlement agreement should prescribe the general contours of the distribution mechanism. For instance, the agreement might prescribe categories of compensable diseases or injuries and might list factual and legal issues that may or may not be considered in determining settlement values.

In the Dalkon Shield situation, for example, the trust agreement governing payments for Dalkon Shield personal injury claims prescribes certain procedures for settling claims and sets forth the factors that may be considered in determining compensation levels. However, the trust agreement leaves to the discretion and judgment of the trustees the determination of appropriate levels of compensation and the weight to be given to various individual factors, such as the type of proof presented to the trustees for their evaluation of individual claims.

\section{III}

\section{Distributing the Fund-Developing And Implementing a Distribution Mechanism}

Once an overall, aggregate settlement has been achieved, attention must turn to the mechanics of resolving the individual claims of hundreds, sometimes thousands, of claimants. This involves the establishment of a delivery system to distribute the settlement fund.

The critical issue in designing a mass tort settlement delivery system is developing a procedure that will provide compensation to eligible claimants efficiently and fairly without duplicating the delays and costs associated with resolving claims through litigation. This poses a significant challenge, however, because minimizing administrative costs almost inevitably means

43. In some cases, however, the settlement agreement will leave the determination of how to distribute monies to individuals to the discretion of future administrators of the settlement fund. In the Agent Orange case, for example, the settlement agreement contained no guidelines whatsoever for compensating individuals. See In re "Agent Orange" Product Liability Litigation, 597 F Supp 740, 862 (ED NY 1984). Once the parties agreed to an aggregate settlement amount, the court-appointed special master developed a proposed distribution plan, which was ultimately adopted by the court. See In re "Agent Orange" Product Liability Litigation, 611 F Supp 1369 (ED NY 1985). 
circumventing some of the traditional litigation procedures that determine the value of an individual claim. For this reason, some critics have concluded that administrative compensation schemes that call for a mass resolution of cases or establish scheduled payments are dehumanizing, unfairly fail to take account of significant differences among claimants, and are contrary to certain fundamental values of our civil justice system. ${ }^{44}$

The difficulty with a detailed, case-specific approach, however, is that a compensation system that calls for in-depth, individualized scrutiny of each of thousands or tens of thousands of claims impedes the speedy recovery that makes settlement attractive to plaintiffs. In fact, the detailed examination of individual claims is one of the principal factors that has made the resolution of mass torts through the traditional litigation system an unsatisfactory process.

It is not within the scope of this article to participate more fully in this debate regarding the appropriateness of different procedures for the mass resolution of claims. It is the author's belief that an aggregate settlement coupled with a streamlined compensation system can resolve individual claims effectively without sacrificing fundamental fairness. Although some individual factors traditionally accounted for in the litigation process may not receive the same degree of consideration in an aggregate compensation scheme, a wellconceived and well-executed settlement distribution system that provides speedy and consistent compensation is ultimately preferable to litigating thousands of individual claims.

This section of the article focuses on establishing an administrative system for resolving claims and distributing funds to individual plaintiffs. The section addresses the issues of developing distribution procedures and compensation levels, as well as the practical considerations involved in setting up a claims resolution facility.

\section{A. Developing a Compensation Scheme}

The most challenging aspect of establishing an administrative claims resolution procedure is the development of the "compensation scheme" to be used in distributing the settlement fund to the individual plaintiffs. In this context, "compensation scheme" is meant to encompass both the procedural

44. Attempts to resolve mass tort controversies in the aggregate have generated much debate among commentators. Critics argue that a mass resolution of claims involving the use of administrative procedures to distribute payments is contrary to certain fundamental principles of the civil justice system. The mass resolution of claims tends to preclude the parties' ability to vindicate their actions and obtain a formal finding that characterizes the actions of their opponent as harmful or wrong. See Novey, $27 \mathrm{~J} \mathrm{Soc} \mathrm{Sci} \mathrm{\&} \mathrm{Med} \mathrm{at} \mathrm{1071,} 1079$ (cited in note 9). This vindication of rights is seen by some as a basic value of the tort system. Other critics argue that mass resolution procedures inevitably result in overpayments to individuals with relatively weak claims and underpayments to those with relatively strong claims. This criticism assumes that the current tort system places consistent and appropriate values on claims. In reality, however, plaintiffs are likely to obtain vastly different results in different jurisdictions. Even within a given jurisdiction, different juries and different judges may place different values on similar claims. The debate regarding the use of aggregative procedures in mass tort cases is discussed in Peterson \& Selvin, Resolution of Mass Torts at ix-x (cited in note 16). 
guidelines for distributing monies and the establishment of particular settlement values.

1. Establishing Procedural Compensation Guidelines. A variety of procedural mechanisms may be used in distributing the settlement monies to eligible plaintiffs. These mechanisms range from a simple process not unlike a workers' compensation system, under which plaintiffs submit specified materials and receive a predetermined payment, to a more complex process involving individual case evaluations or even case-by-case negotiations. Obviously, as the process becomes more complex and individualized, it also becomes more expensive and time consuming.

The selection of the appropriate procedural mechanism for distributing money is closely tied to the issue of valuation of claims. As the valuation of particular claims becomes more and more dependent on the individual characteristics of the plaintiff, the procedures established for processing claims will necessarily incorporate more individualized case-by-case analysis.

Finally, a compensation scheme need not rely on any single claims resolution procedure. A compensation scheme that utilizes a variety of mechanisms for distribution might be best able to meet the needs of different categories of plaintiffs. The Dalkon Shield compensation scheme, explained in Part IVE below, illustrates the spectrum of distribution mechanisms and demonstrates that a single distribution plan can encompass a variety of procedures.

2. Establishing Settlement Values. The determination of appropriate, fair, and acceptable settlement values is critical to the success of any administrative distribution mechanism. Not surprisingly, this task often proves to be the most challenging and controversial aspect of the entire settlement process. The following discussion examines the issues that must be considered and the decisions that must be made in establishing settlement values.

a. Criteria for payment. In formulating the settlement value for individual claims, it is first necessary to establish the criteria that will be used in determining eligibility for payment. Some of the key issues that must be considered in developing such criteria are set forth below.

(i). Defining compensable injury and the universe of eligible plaintiffs. The first criterion that must be established is the definition of a compensable injury. In mass toxic tort controversies, the plaintiffs may allege that the harmful substance caused a variety of different types of injuries that range from relatively minor afflictions to serious and often fatal diseases. For example, in the Agent Orange litigation, the plaintiffs alleged that exposure to the herbicide caused injuries ranging from a serious skin ailment (chloracne) to liver disease, cancers and death. Similarly, individuals exposed to asbestos claim that asbestos fibers cause not only asbestosis and mesothelioma, but also lung cancer, colon cancer, pharyngeal cancer, and other malignancies. 
In order to establish a workable compensation scheme, therefore, the parties (or the fund administrators) must also define the types of injuries or diseases that will be compensable. In addition, the administrators must define the type of damage for which compensation will be paid. For instance, the fund might limit compensation to claims of physical injury alone or it might provide payment to claimants who suffer economic and non-economic loss, or it might even distribute payments for emotional distress, enhanced risk of disease, and derivative injuries (such as loss of consortium).

Another fundamental consideration in determining the compensation formulas is the issue of the universe of eligible plaintiffs. As noted earlier, mass tort situations typically involve latent injuries that may not manifest themselves for several years following exposure. Indeed, the injurious consequences of some mass torts manifest themselves in future generations.

Whether and how to cover claims that arise in the future is a crucial consideration in structuring a compensation scheme. If future claims are to be provided for, the compensation scheme must be arranged to ensure that funds will not be depleted before such claims arise. One option for ensuring that sufficient funds are available for future claims may be to set aside a certain percentage of the compensation fund as an insurance fund that will benefit claimants who become disabled in the future. ${ }^{45}$

(ii). Causation/standards of proof. Closely linked to the question of what injuries to cover is the issue of causation-that is, to what extent should causation play a role in the compensation formula? The answer to this question will likely depend on the history of the litigation and the state of the medical and scientific knowledge regarding the link between the harmful substance and the injury.

In a typical case, compensation guidelines will give some degree of consideration to the issue of causation. The fund administrators must determine the type and amount of proof of causation that will be required in order to receive compensation. Where proof of causation is difficult-for example, where the injuries alleged could be caused by a variety of factors other than the product at issue or where exposure to the product is difficult to determine-an efficient compensation scheme might establish certain assumptions regarding causation. These assumptions might include not only assumptions about the categories or types of diseases or injuries that will be presumed to have been caused by the harmful product, but also assumptions regarding the existence of the disease or exposure to the product. Other issues that must be determined include the appropriate treatment of potential

45. Determining how much money will be necessary to compensate future claims is a formidable task in itself. This determination will involve a comprehensive analysis of existing claims, predictions about the incidence of injury in the potential claimant population, and estimates about the number of eligible persons who will actually seek compensation from the fund. The number of individuals who actually assert claims in the future can depend on unpredictable factors such as notice of the settlement fund's existence and the process established to file a claim. 
contributing causes of the injury at issue: will such causes affect the value of the individual claim, or will they simply alter the plaintiffs' burden of proof?

The assumptions and standards developed with respect to proof of causation can be flexible. Assuming the claims resolution procedures provide a degree of flexibility, the amount of compensation can be varied depending in part on the amount and type of proof of causation available.

In some extreme cases, causation may be excluded from the compensation scheme. Under the Agent Orange distribution plan, for example, claimants are not required to demonstrate any causal relationship between their health problems and exposure to Agent Orange. The court in the Agent Orange litigation determined that requiring proof of individual causation would place an unreasonable burden upon the plaintiffs because the scientific evidence was not sufficiently certain to support a distribution plan that would limit eligibility for compensation to individuals with specific diseases. Accordingly, the distribution plan adopted by the court requires only that plaintiffs demonstrate the existence of a disabling disease or death from a nontraumatic source and a probability of exposure. ${ }^{46}$

(iii). Legal issues. Various legal issues are also important in developing a compensation system. As noted, mass tort cases often span numerous jurisdictions and may even include claims filed in other countries. One factor that must be considered in establishing a compensation scheme is whether and how to take into account particular legal requirements, such as statutes of limitations or limitations on damages, of the particular jurisdiction in which the claim arose.

(iv). Personal characteristics. In an ordinary tort case, an individual plaintiff's recovery might depend upon the jury's sympathy for the plaintiff's situation, the existence of dependents, and intangible factors such as extraordinary pain and suffering. In establishing settlement formulas, the fund administrators must also consider whether and to what extent these personal characteristics of individual plaintiffs should be taken into account.

b. Valuation of injuries. Finally, the fundamental and most important issue that must be addressed in developing a compensation scheme is establishing a method for determining the value of various injuries. Weighing the value of, for example, cancer versus a thyroid deficiency versus a particular birth defect can be perplexing, but it is a necessary task in the development of compensation formulas. In the traditional litigation model, claims are evaluated on a case-by-case basis, taking into account a variety of factors, including the strength and credibility of the evidence, the plaintiff's economic loss, the existence of dependents, intangibles such as pain and suffering, and other factors that might have contributed to the injury. In settling an individual tort claim, the parties may consider additional factors

46. In re "Agent Orange" Product Liability Litigation, 611 F Supp 1396, 1412-17 (ED NY 1985). 
such as the financial wherewithal of the defendant, the status of the litigation, and the relative skill of the attorneys. In the context of a mass tort settlement distribution, it seems advisable to develop some standardized procedures and valuation methods in order to achieve the goal of providing fair compensation with a minimum of transaction costs.

One method might be to establish claim values based on historical compensation data. Such historical data can be compiled and analyzed to reveal the effect of various factors on recovery in past claims arising out of the same mass tort. ${ }^{47}$

Deciding precisely what data to include in the analysis, however, involves several questions. For example, should trial results be discounted by the amount of punitive damages awarded? Should the available data be analyzed on a national basis or on a regional basis? Should differences in state law be factored into the analysis? Should the data be adjusted for inflation? Thus, although the historical data, if available, may be the most justifiable basis for determining settlement values, the task of collecting and analyzing this data is complex and involves a number of difficult determinations.

This is not to say that the valuation of the injury must be the exclusive determinant of a claimant's recovery. Other issues might also be considered. For example, should the compensation formula account for the relative need of individual claimants? In the Agent Orange case, for instance, the court determined that the limited settlement fund should be distributed to those who alleged the most severe injuries and who were most in need of assistance. ${ }^{48}$ Other issues to be considered include the impact of collateral sources of recovery, such as insurance, and allowances for a particular claimant's attorney's fees.

\section{B. Administration of the Settlement Fund-Establishing a Claims Resolution Facility}

Once agreement has been reached on the compensation scheme, the actual mechanism for holding and disbursing monies can be established. The first decision concerning the administration of a settlement fund is to identify some individual or group to administer the fund. In some cases, the parties' attorneys (principally the plaintiffs' attorneys) will take responsibility for administering and distributing the fund. In other cases, the court, or a courtappointed entity or official, might administer the fund. Alternatively, the parties might establish a separate trust, as in the Dalkon Shield example, for the purpose of holding and administering the settlement fund.

The next administrative decision is to determine what type of facility, if any, should be established or selected to manage individual claims. Whether administration of the settlement fund will require a full-fledged claims

47. A software package was developed to analyze historic data regarding settlement of Dalkon Shield claims. See Carol Angel, Lawyers Design Dalkon Settlement Software, 10 i Los Angeles Daily J 5 col 1 (July 8, 1988).

48. See In re "Agent Orange" Product Liability Litigation, 611 F Supp 1396 (ED NY 1985). 
resolution/distribution facility depends on the particular situation. Factors relevant to whether an independent facility is necessary include the number of claims involved, the length of time over which the fund will be distributed, and the method by which individuals are to be compensated. For example, if the overall settlement plan calls for individual negotiation and settlement of a relatively small number of cases (or groups of cases), an independent facility may not be necessary. Rather, the parties may be able to set certain standards for evaluation of individual claims and then handle the individual settlement negotiations without the assistance of a separate professional staff. On the other hand, if the overall settlement agreement envisions streamlined (perhaps even computerized) processing of a massive number of claims, an independent facility run by a professional staff may be necessary to administer the distribution procedure.

1. Establishing a Claims Facility. Essentially, two basic options are available for establishing a facility to conduct the actual claims processing activity necessary to distribute funds to large numbers of claimants. The administrator of the settlement fund can create an in-house mechanism for receiving and processing claims; alternatively the administrator can enter into agreements with outside contractors to provide the necessary services. ${ }^{49}$

There are advantages and disadvantages to both of these options. Hiring an outside contractor has a certain appeal because it presumably avoids the need to create new bureaucracy. By setting up its own in-house facility, the settlement fund or trust acquires all the costs and responsibilities of an ordinary business: it must enter into employment agreements, pay appropriate employee benefits and taxes, obtain various types of liability insurance, enter into rental agreements, and purchase furniture and equipment; it must also maintain (or service) these items. These efforts could be too costly and burdensome, particularly if the settlement fund is to be distributed over a short period of time.

Use of an outside contractor is especially appealing where the tasks to be performed and the decisions to be made are well within the expertise of the contractor. Thus, by hiring existing entities, the settlement fund administrators or trustees can draw upon the institutional knowledge and experience of the contractor. However, this perceived advantage may be illusory. If the settlement fund is to be distributed over a relatively short period of time, the contractor may be unable or unwilling to commit its permanent staff to performing the claims administration functions. Rather, the contractor may rely on part-time and temporary employees, thereby nullifying some of the advantages of hiring a contractor with institutional expertise.

49. Contractors capable of operating a claims facility might include insurance companies with expertise in handling similar types of claims, third-party administrators-that is, entities that typically act as subcontractors to insurance carriers and are experienced in processing large volumes of claims -or even consulting firms. 
Unlike hiring outside contractors, establishment of an in-house facility has the distinct advantage of allowing the settlement administrators to exercise complete control over the operation and to centralize all decision-making. An outside contractor may have institutional needs and concerns that could conflict with the needs of the settlement fund administrators. This could lead to misunderstandings and disputes regarding the activities and priorities of the contractor. ${ }^{50}$

The settlement fund administrator must weigh several factors to determine which of the two options best suit the fund's needs. For instance, the duration of the fund distribution activities can be a key factor in selecting a claims facility. As noted, if the fund is to be distributed over a short period, it might be most advantageous to hire an existing contractor. The fund will have to determine whether the cost savings are likely to outweigh the potential disadvantages of utilizing an outside contractor. If, on the other hand, the fund will be distributed over a period of several years, the expense of establishing an in-house facility might be justified. In addition, the administrator should consider the substantive distribution guidelines. If the requirements for obtaining compensation from the fund require judgments within the expertise of an existing contractor, it might be most advantageous to contract for services. Each settlement will have different needs and concerns, each of which must be evaluated in determining the appropriate facility for administering claims.

2. Payment/Fund Management. Another administrative issue confronting the parties is the establishment of a system for collecting, holding, and managing the funds prior to distribution to the eligible plaintiffs. First, the parties must determine how this aggregate amount is to be paid by the defendants. There are several options. The defendants might prefer to pay the agreed upon amount into an account in one lump-sum. The account would hold the funds pending distribution. This is essentially the method used in the Agent Orange litigation. ${ }^{51}$ Similarly, under the Dalkon Shield settlement, the Trust received the bulk of its funding in one lump-sum payment. ${ }^{52}$

Alternatively, the funds could be paid over a period of time, using a method similar to that used in a traditional structured settlement. This approach has the advantage of minimizing the initial financial impact on the defendants but has the disadvantage of postponing the defendants' goal of achieving total peace. Moreover, if an installment payment system is used, the

50. For example, the company may be structured in such a way as to require the cooperation of several different departments in completing one task for the settlement fund. Since each department is likely to have responsibilities other than to the fund, it may be difficult for the contractor to commit to providing all the services desired by the fund quickly.

51. In re "Agent Orange" Product Liability Litigation, 597 F Supp 740 (ED NY 1984), modified, 818 F2d 145 (2d Cir 1987).

52. See generally Dalkon Shield Claimants Trust, Sixth Amended and Restated Plan of Reorganization Disclosure Statement ("Disclosure Statement"). 
plaintiffs are likely to demand assurance that the defendants will be able to comply with the obligation.

Second, the parties or the settlement fund administrator must determine how to manage the monies pending distribution. In a mass tort settlement, distribution is likely to take years. Accordingly, the funds must be managed in such a way as to both assure that sufficient monies will be available for distribution and that the funds will be secure. The settlement fund administrators or trustees will probably enter into an arrangement with investment managers and banking institutions to both manage the investment of funds and arrange for liquidation and disbursement when necessary. The fund administrators will have to establish guidelines for the investment of funds to assure the degrees of security and liquidity necessary to meet the fund's obligations.

Finally, in establishing a settlement fund and delivery system, the parties and/or the fund administrator must consider the tax consequences of the fund and its distribution activities. Depending on how the fund is organized, it may be deemed an entity subject to tax under both state and federal tax laws. Moreover, depending on the composition of the settlement fund, payments or portions of payments to individual plaintiffs may be taxable. If so, the settlement fund may be required to institute appropriate tax withholding and reporting procedures.

\section{IV}

\section{Case History: The Dalkon Shield Claimants Trust}

The resolution of the Dalkon Shield personal injury cases illustrates the process, issues, and difficulties involved in implementing an aggregate resolution of a mass tort controversy and in establishing a mechanism for settling the individual claims.

\section{A. Background}

The Dalkon Shield litigation began in 1971 when a number of women who had used the Dalkon Shield intrauterine device began filing lawsuits against the A.H. Robins, Co. ("Robins"), the sole manufacturer and distributor of the device. The women claimed that the Dalkon Shield caused a variety of injuries, including ectopic pregnancy and septic abortion. Most claimants sought both compensatory and punitive damages on a variety of theories, including negligence and negligent design, strict products liability, breach of express and implied warranties, and wanton and reckless conduct. By 1985 , Robins had disposed of more than 9,000 claims and faced an additional 5,000 cases pending in state and federal courts. At this point, Robins and its insurer had paid out approximately $\$ 530$ million in both compensatory and punitive 
damages to individuals who had been injured in some manner by the Dalkon Shield. ${ }^{53}$

By 1974, when it discontinued sales of the device, Robins had sold approximately 2.2 million Dalkon Shields. The mounting number of personal injury claims and the enormous potential liability led Robins to seek protection under chapter 11 of the Bankruptcy Code. On August 21, 1985, Robins filed a petition for bankruptcy in the United States Bankruptcy Court. The bankruptcy proceeding was conducted by Judge Robert A. Merhige, Jr., United States District Judge for the Eastern District of Virginia. ${ }^{54}$

\section{B. Aggregate Resolution}

After filing for bankruptcy, Robins took two actions that ultimately enabled it to achieve a comprehensive and final resolution of all the personal injury claims. First, Robins sought to establish a "bar date" by which all individuals who potentially had a personal injury claim against Robins resulting from the Dalkon Shield must file a claim. Upon Robins's motion, the court ordered that all present and future Dalkon Shield personal injury claimants must file a claim by April 30, 1986 or they would be barred from seeking compensation for an injury related to the Dalkon Shield. ${ }^{55}$ By instituting the bankruptcy proceeding and establishing this bar date, Robins effectively consolidated all present and future Dalkon Shield personal injury claims in one forum, making it possible to resolve its total liability in one action.

Second, Robins proposed the establishment of a "closed fund" from which all Dalkon Shield personal injury claimants (both present and future) would receive compensation. Representatives of the claimants opposed the proposal, arguing that the claimants should not shoulder the risk of an inadequate fund. They proposed that Robins be sold and the proceeds used to pay the claimants ${ }^{56}$ or, in the alternative, that an unrestricted fund be created from which the claims would be satisfied.

To resolve this dispute, Judge Merhige appointed an expert to devise a mechanism for estimating the value of the Dalkon Shield personal injury claims. ${ }^{57}$ If the total value of the claims could be determined, the parties

53. In re A.H. Robins Co., Inc., $880 \mathrm{~F} 2 \mathrm{~d}$ at 717 .

54. In re A.H. Robins Co., 88 BR 742 (ED Va 1988).

55. Id at 745. Robins spent several million dollars in advertising costs in an attempt to notify potential claimants of this bar date. Ultimately, over 300,000 individuals filed claims in response to the advertising effort. After invalid claims were eliminated through distribution of questionnaires, approximately 195,000 claims remained. Id. The guidelines ultimately adopted for distribution of compensation to Dalkon Shield claimants include provisions for paying "late claims" under certain conditions.

56. Under bankruptcy law, the personal injury claimants take priority over the equity holders. 11 USC $\$ 1171$. Thus, all personal injury claimants had to be satisfied before any money was allocated to equity.

57. In re A.H. Robins Co., Inc., 88 BR at 746 (appointing Francis E. McGovern). Section 502(c) of the Bankruptcy Code requires that any contingent or unliquidated claim, the fixing or liquidating of which would delay the administration of the case, shall be estimated. 11 USC $\$ 502$ (c). To try each claim separately would likely have consumed Robins's assets. Accordingly, the Fourth Circuit 
might be able to agree on establishing a fund to compensate all personal injury claims. Even if the parties could not agree on establishing a fund, the court could use the evidence developed in the estimation process to determine Robins's total liability for the Dalkon Shield personal injury claims. The activities of the court-appointed expert in the Robins bankruptcy encompassed two areas: development of guidelines for distribution of a fund to Dalkon Shield claimants and collection of the information necessary to place an aggregate value on the present and future claims. ${ }^{58}$

The data collection was designed and conducted so as to obtain the same type of information that would ordinarily be used in evaluating any individual personal injury case. In other words, the data collection activities were based on a litigation model, using instruments similar to those normally used in litigation. Questionnaires distributed to claimants incorporated the same sort of questions that would be asked in interrogatories or depositions. There were some obvious limitations. The collection of massive data cannot possibly take into account such personal characteristics as the credibility or the sympathetic nature of particular plaintiffs, which would be factors in evaluating individual cases.

The data collection included extensive examination of a sample of the 9,000 claims that had already been resolved and distribution of a questionnaire to several thousand claimants who were randomly selected from the group of pending claims. ${ }^{59}$ The questionnaire sought information on such items as medical history, use of the Dalkon Shield, medical problems, illness or injury claims related to the Dalkon Shield, claims of future problems, and financial losses. ${ }^{60}$ The data were used to compile a comprehensive database that contained a record of historical litigation and settlement data as well as a profile of existing claims. The information gathered through this process was then distributed to the parties for use in preparing their own estimates of the aggregate value of the claims. The process of collecting, reviewing, and compiling the evidence of the value of the claims took more than one year.

In the fall of 1987, Judge Merhige held extensive hearings at which each of the parties' various experts testified as to their estimation of the amount of money that would be necessary to compensate existing and future claims.

suggested that the district court "arrive at a fair estimation of the value of all the claims." A.H. Robins $v$ Piccinin, 788 F2d at 1013.

58. In re A.H. Robbins Co., Inc., $880 \mathrm{~F} 2 \mathrm{~d}$ at 699 . It was assumed that the parties and the court would be unable to estimate the value of the claims without a reasonable understanding of the conditions under which payments would be distributed. The claims resolution guidelines eventually adopted are described in detail in Part IVE.

59. Examination of the previously resolved claims included a re-creation of complete litigation files for each individual in the sample. Once this information was collected, medical reviewers compiled and coded medical information. The theory behind this process was that comprehensive historical data on the factors that determined the value of particular claims could be used to estimate the value of the unresolved claims once the characteristics of the pending claims were analyzed.

60. The information collected from pending claimants was quite extensive. A fifty-page form was sent to 6,000 individuals, who also were asked to submit medical records. 
The proposed value of the claims ranged from $\$ 800$ million (suggested by Robins) to $\$ 7$ billion (suggested by the "Claimants Committee," a group of attorneys that represented the Dalkon Shield plaintiffs). ${ }^{61}$ According to the experts who compiled the data, the variation in the estimated aggregate value of the claims was attributable to different assumptions regarding such issues as the applicability of statutes of limitations, the level and type of proof of both Dalkon Shield use and injury that should be required to obtain compensation, the effect of potential alternative causes of the injury, the evaluation of the historical cases, and the number of individuals who would pursue claims.

After hearing the evidence submitted by the parties, the district court determined that the aggregate value of the claims was $\$ 2.475$ billion, payable over a reasonable period of time. ${ }^{62}$ This determination of the aggregate liability paved the way for Robins to pursue a merger in order to reorganize the company. In February 1988, Robins reached an agreement with American Home Products ("American Home") under which Robins would be merged into a subsidiary of American Home. On March 28, 1988, Robins submitted to the court a consensual plan of reorganization that called for the establishment of a trust fund, the Dalkon Shield Claimants Trust ("the Trust"), to provide compensation for individuals claiming injury from the Dalkon Shield. ${ }^{63}$ Under this plan, neither Robins nor American Home would have any potential liability for Dalkon Shield claims. Rather, the Trust would assume all such liability. The bulk of the money used to fund the Trust would be generated by the merger. ${ }^{64}$

\section{The Dalkon Shield Claimants Trust}

Under the plan of reorganization, the Dalkon Shield Claimants Trust was established as a Designated Settlement Fund under the Internal Revenue Code. ${ }^{65}$ The Trust assumes the liability of Robins and Robins's successors for Dalkon Shield personal injury claims, and is required to satisfy such claims "fairly and expeditiously," according to guidelines set forth in the plan of reorganization. A central feature of the plan is an injunction against any action, except malpractice actions, by Dalkon Shield claimants against any person or entity other than the Trust for Dalkon Shield related claims. The Trust agreement provides for the appointment of five trustees who are

61. Robins estimated that claims would total between $\$ 0.8$ and $\$ 1.3$ billion, while the Claimants Committee's estimate was $\$ 4.2$ to $\$ 7$ billion. The other estimates were: $\$ 1.03$ billion (equity security holders), $\$ 1.54$ billion (unsecured creditors), and $\$ 2.2$ to $\$ 2.5$ billion (Aetna). In re A.H. Robins Co., 880 F2d at 699 .

62. In re A.H. Robins Co., $88 \mathrm{BR}$ at 747.

63. Robins's proposed plan of reorganization was confirmed by the district court on July 26 , 1988. In re A.H. Robins Co., 88 BR 742. As discussed in more detail in Part IVD, the district court's decision was affirmed. 880 F2d 694 (4th Cir), cert denied, 110 US 331 (1989).

64. In re A. H. Robins Co., 880 F2d at 720-21.

65. 26 USC $\$ 468 \mathrm{~B}$. 
responsible for carrying out all operations and activities of the Trust, including investing and managing the Trust's assets. ${ }^{66}$

The Trust received funds from several sources. The primary source of funds for the Trust was the money generated by the merger between Robins and American Home. Robins was required to pay $\$ 2.255$ billion into the Trust once the plan became final, that is, after all appeals were exhausted. ${ }^{67}$

In addition, the Trust received $\$ 5$ million from $\mathrm{E}$. Claiborne Robins and $\mathrm{E}$. Claiborne Robins, Jr., as well as funds from the settlement of a class action suit (commonly referred to as the Breland case) brought by Dalkon Shield claimants against Aetna (Robins's insurer) alleging that Aetna and Robins had improperly settled litigation regarding the scope of Robins's insurance coverage. ${ }^{68}$ Under the Breland settlement, approved by the district court in July 1988 and by the Fourth Circuit in June 1989, the Trust receives: (1) $\$ 250$ million in insurance from Aetna, (2) $\$ 50$ million cash from Aetna, and (3) $\$ 25$ million cash from the successor corporation, to be paid out of Aetna money. Finally, the Trust will receive approximately $\$ 45$ million in unused insurance that Robins holds for the Dalkon Shield, and it may also receive funds from the Dalkon Shield Other Claimants Trust. ${ }^{69}$

\section{Appeals}

After the plan of reorganization was confirmed by the district court on July $26,1988,{ }^{70}$ various plaintiffs' attorneys appealed. For example, a group of Dalkon Shield claimants who voted against the Plan challenged four aspects of it. ${ }^{71}$ First, they challenged the district court's approval of the disclosure

66. In re A.H. Robins Co., $880 \mathrm{~F} 2 \mathrm{~d}$ at 700 .

67. Disclosure Statement at 37 (cited in note 52).

68. Shortly after Robins filed the bankruptcy petition, a number of Dalkon Shield claimants filed a class action suit against Aetna Casualty and Surety Company (Robins's Insurer) as well as Robins's officers to recover for injuries resulting from the use of the Dalkon Shield. Breland v Aetna Casualty $\mathcal{F}^{\circ}$ Surety Co., 88 BR 755 (ED Va 1988). Although the case was originally filed in the District of Minnesota, it was transferred to the Eastern District of Virginia, where the Robins bankruptcy case was proceeding. The claimants alleged that Aetna was jointly liable with Robins and others for Dalkon Shield injuries under a theory of joint enterprise or conspiracy. They contended that Aetna was an active participant in the development and promotion of the Shield and was responsible equally with Robins for Robins's failure to recall the Shield until 1984. The court certified two separate classes of claimants consisting of persons who had filed timely claims against Robins and persons who had not. Ultimately the Breland plaintiffs and Aetna agreed to a settlement under which Aetna would contribute to the Dalkon Shield Claimants Trust established under Robins's plan of reorganization and provide some insurance if the Trust fund proved to be insufficient. The settlement does not, however, provide for the contribution of unlimited funds should the Trust have insufficient monies to pay all claimants. As noted, the Breland settlement was affirmed by the Fourth Circuit. In re A.H. Robins $\mathcal{E}$ Co., 880 F2d 709 (4th Cir 1989). A petition for certiorari was filed on September 14, 1989, sub nom Anderson v Aetna Casualty $\&$ Surety Co. The Supreme Court denied certiorari on November 6, 1989. 110 S Ct 376.

69. Under the plan of reorganization, Robins is to establish the "Dalkon Shield Other Claimants Trust." The purpose of this trust is to pay claims other than personal injury claims or related claims. This trust will provide compensation for claims for indemnification of doctors and hospitals. Disclosure Statement Annex 1 at PLN-9-12 (cited in note 52).

70. In re A.H. Robins Co., 88 BR 742.

71. In re A.H. Robins Co., 880 F2d 694. 
statement contained in the Plan. ${ }^{72}$ Second, they disagreed with the district court's use of a one claimant/one vote voting procedure. ${ }^{73}$ Third, they disputed the district court's finding that the Plan was "feasible"-that is, would pay all claimants in full and avoid the need for further reorganization. ${ }^{74}$ Finally, they challenged the provision enjoining all suits by Dalkon Shield victims against third parties. ${ }^{75}$ The Fourth Circuit rejected these challenges and upheld the Plan on June 16, 1989.76 On September 14, 1989, these claimants filed a petition for certiorari in the United States Supreme Court challenging the injunction prohibiting actions against third-party joint tortfeasors. The Supreme Court denied certiorari on November 6, 1989.77

\section{E. Distribution Mechanism-The Dalkon Shield Claims Resolution Facility}

The compensation scheme established by the Dalkon Shield Claimants Trust illustrates both the complexities of developing a workable distribution procedure and the issues involved in determining settlement values. Under the claims resolution guidelines set forth in the Trust agreement, claimants may select one of three options for obtaining compensation. ${ }^{78}$ Each of the options employs a different compensation formula and a different means of evaluating claims.

The Dalkon Shield claims resolution guidelines are based on the assumption that different claims resolution techniques are appropriate for different claimants and that the claimant is in the best position to determine the optimum procedure for resolving the claim. In general, the various options represent a trade-off between speed and level of recovery, on the one hand, and evidentiary requirements and evaluation of individual factors, on the other. The options range from a simple flat payment schedule, offering modest sums for applicants with minor injuries, to an intensive, individualized negotiation/litigation process. By allowing the claimants to select the resolution option, the fund presumably avoids the need to expend its limited

72. The claimants argued that the disclosure statement contained in the plan did not contain sufficient information for them to determine whether to support the plan. The Fourth Circuit concluded that the district court did not abuse its discretion in finding the statement to be adequate. Id at 697-98.

73. The claimants argued that the district court violated statutory procedures for voting on the plan contained in 11 USC $\$ 1126$ (a) by assigning the value of one dollar to each Dalkon Shield claim. The claimants contended that the statute mandates weighted voting. The Fourth Circuit concluded that any error was "harmless" in light of the overwhelming vote in favor of the plan. Id.

74. The claimants challenged the district court's failure to clarify the components of its determination that $\$ 2.475$ billion would be sufficient to pay all the claims. The Fourth Circuit concluded that the estimate of $\$ 2.475$ billion was not clearly erroneous. Id at $698-700$.

75. The claimants challenged the plan's imposition of a permanent injunction barring Dalkon Shield claimants from obtaining recovery against third-party joint tortfeasors such as officers and attorneys, doctors, clinics, hospitals, and distributors of the Dalkon Shield. The claimants contended that suits against such third parties may be the only way to provide payment in full to Dalkon Shield claimants should the Trust prove to have insufficient funds. Id at 700-01.

76. In re A.H. Robins Co., 880 F2d 694.

77. Menard-Sanford v A. H. Robins Co., 110 S Ct 376 (1989).

78. Claimants may elect a fourth option under which they can defer consideration of their claim. Disclosure Statement Annex 4, Exhibit C par 4 (cited in note 52). 
resources culling out weak or illegitimate claims. Those individuals who are unable or unwilling to produce any substantial evidence of a Dalkon Shield related injury or who have suffered only minor injuries would presumably select the "modest payment" option. Individuals with stronger evidence or greater injuries will be inclined to select an option providing for a more intensive and more individualized resolution, which is likely to produce a larger payment. The discussion following presents an overview of each of the available options.

1. Option 1-Short Form. Option 1 establishes a quick payment scheme for claims involving minor injury or where the claimant cannot demonstrate Dalkon Shield use. It is intended to encourage quick and efficient resolution of de minimis claims. The claimant receives only a modest payment but is not required to submit detailed proof of injury. Instead, the claimant need only execute an affidavit attesting that she used the Dalkon Shield and was injured (or believes she may have been injured) or that he or she was injured because of another person's use of a Dalkon Shield. By instituting this de minimis payment option, the Trust has opted for a cost-efficient approach to the issue of potentially illegitimate claims. The assumption is that it is less expensive to pay a modest sum to a claimant with no proof of harm related to the Dalkon Shield than to investigate the legitimacy of such claims. Because the claimant decides whether to pursue this option-that is, the claimant may decide to forgo option one and pursue the other option-the possibility that individuals with legitimate and valuable claims will be underpaid is minimized.

The Trust has established three levels of payments for claimants who elect to proceed under Option 1: Persons who assert a personal injury as a result of using the Dalkon Shield receive a lump sum of $\$ 725$; persons who assert a derivative injury receive $\$ 300$; and persons whose documentation reveals a conflict (for example, persons who actually may have used a different intrauterine device) receive $\$ 125$. Approximately 40 percent of all active claims have been resolved through Option 1. As of August 30, 1989, the Trust had paid 80,538 Option 1 claimants a total of $\$ 52,183,875$.

2. Option 2-Claim Form/Tailored Offer. Option 2 is intended to be used to resolve the bulk of Dalkon Shield claims. Under Option 2, the trustees developed a payment schedule setting forth specified settlement amounts for a number of compensable injuries as set forth in the Trust agreement. These injuries include pelvic inflammatory disease, perforation caused by the Shield, and abortion occurring as a result of pregnancy while the Shield was in place. (The trustees may add other injuries to the current list of compensable injuries.)

Under Option 2, claimants generally will receive a higher payment than under Option 1. However, to obtain that payment, the claimant must produce significantly more evidence of injury. The claimant is required to attest to specific injuries and to answer questions under oath regarding the use of the Dalkon Shield. Claimants must also submit medical records or an affidavit of 
a health care provider evidencing Dalkon Shield use as well as medical records documenting the injury. If a claimant selects Option 2, the Trust waives all defenses to the claim, except for challenges based on such factors as duplicate claims, late filing, and disallowed claims.

Whether to accept the Option 2 payment schedule is at the sole discretion of the claimant. However, once a claimant elects to proceed under Option 2, the claimant may not proceed to Option 3 unless she or he was denied compensation by the Trust under Option $2 .{ }^{79}$

Option 2 is intended to provide moderate, standardized payments to individuals with relatively mild injuries. The assumption underlying the Option 2 scheduled payments is that the majority of the remaining claims do not involve the sort of substantial and serious injuries that require individualized examination and evaluation to determine an appropriate payment level. Payments available under Option 2 range from $\$ 400$ for a loss of consortium claim by the spouse of a Dalkon Shield user to $\$ 5,500$ for a user who had certain conditions (such as pelvic inflammatory disease) that resulted in nonvoluntary sterilizing surgery. Among the injuries that may be compensated under Option 2 are birth defects, infant death and septic absorption caused by pregnancy while the shield was inserted, ${ }^{80}$ nonsurgical infertility, ${ }^{81}$ pelvic inflammatory disease, ${ }^{82}$ uncontrolled bleeding, ${ }^{83}$ and perforation or embodiment of the Shield resulting in surgical removal. ${ }^{84}$ Option 2 will be a success if the payment schedule is attractive to a large number of claimants. As of August 1991, a total of 15,679 individuals had applied for Option 2 payments. Of the 11,844 individuals who fulfilled the Option 2 requirements, 11,401 have received compensation totalling $\$ 32$ million.

3. Option 3-Complete Form/Early Evaluation/Offer/Arbitration/Trial. Claimants who do not resolve their claims under Options 1 or 2 may proceed under Option 3. Option 3 claims are to be treated in a more individualized fashion. Under this option, the Trust is required to evaluate each claim based on several criteria, including the quantum and quality of the evidence supporting the claim, the absence of discovery, and the waiver of defenses. The Trust is to compare the individual claim against historical profiles of similar claims and, based on this comparison, determine an appropriate settlement value for the claim.

Under Option 3, the claimant must submit a comprehensive information form and medical records detailing both use of the Dalkon Shield and injuries

79. Id. at Exhibit D.

80. The payment schedule provides $\$ 1,150$ for such birth defects, $\$ 3,200$ for infant death, and $\$ 2,500$ for septic abortion.

81. The payment schedule provides $\$ 3,900$ for this condition.

82. The payment schedule provides $\$ 1,250$ for this condition.

83. The payment schedule provides $\$ 850$ for this condition.

84. The payment schedule provides $\$ 1,500$ for this condition. 
resulting from its use. Option 3 is divided into several levels, each involving different procedures and types of proof.

a. Level one-early evaluation/offer. Under Option 3, the Trust must first evaluate the claim using the following procedures:

(1) The Trust must develop a profile of the claim based on criteria relevant to the value of the case (relevant criteria include the nature of the injury, the medical evidence available to prove the injury and Dalkon Shield use, the presence of other potential causes of the injury, and the length of time since the injury);

(2) the Trust must then compare the profile to other claim profiles based on historical data; and

(3) the Trust must establish a payment amount for the claim, taking into account historical data, the amount and quality of the evidence, the absence of in-depth discovery, and the waiver of certain defenses jy the Trust.

Next, based on this evaluation, the Trust is obligated to make an offer to the claimant. The offer must include a statement of reasons for the offer. The claimant must accept or reject the offer in writing. If the claimant rejects the offer, she may make a counteroffer. If the parties do not resolve the matter through this offer/counteroffer process, the claim will proceed to the next level.

b. Level two-in-depth evaluation/offer/settlement conference or alternative dispute resolution. If the claim is not resolved at level one, the Trust is to undertake an in-depth review of the claim and invite the claimant to a voluntary settlement conference or other voluntary alternative dispute resolution process. This conference is to be held at a location convenient to the claimant. The claimant (or her representative) and a representative of the Trust must be present at the conference. Either side may also have legal counsel present. No later than sixty days after the conference, each side must submit a written settlement proposal to the other side. These offers are to remain in effect until ninety days after the conference. If the parties do not agree, the claimant may proceed to level 3-binding arbitration or trial.

c. Level three-binding arbitration/trial. If the claimant elects binding arbitration, a neutral third party 85 is to select an arbitrator. The arbitration is to be held in a location that minimizes travel for the claimant. In evaluating the claim, the arbitrator may consider the record, the offers made by each side, medical evidence, and the parties' arguments. Both the Trust and the claimant may be represented by advocates. The arbitrator may also solicit

85. In April 1991, the Trust selected the Private Adjudication Center, Inc., which is affiliated with the Duke University School of Law, as the neutral third party responsible for handling the procedural matters related to the binding arbitration related to the Trust. 
independent advice from a panel of doctors or other experts maintained by the Trust. In binding arbitration, the Trust may assert all defenses except product defect. The arbitrator is to issue a written award-enforceable under the Federal Arbitration Act-or denial of the claim. If the claimant elects to go to trial, she or he must file a complaint in the appropriate venue, naming the Trust as defendant. The claimant has a right to a trial by jury. The claim will be handled pursuant to the rules governing litigation in the court in which the case is filed.

d. Summary of option 3. The individualized claim resolution process envisioned in Option 3 will be significantly more costly and time consuming to implement than either Options 1 or 2. If, after Option 2 claims are resolved, the Trust is left with relatively few claims, the process of individual evaluation and negotiation should not prove unduly burdensome or costly. If, however, a significant number of claimants reject Option 2, the Trust could find itself overwhelmed by the Option 3 process.

The accuracy of the court's estimate of the aggregate value of the claims will be put to the test at this stage. The aggregate estimate necessarily included assumptions about the number of claimants who would pursue claims beyond Options 1 and 2. Should fewer individuals than expected resolve their claims under Options 1 and 2, the Trust may face the possibility that insufficient funds will be available to administer and pay Option 3 claims. Whether the Trust can manage the Option 3 claims process in a cost effective and timely manner depends to a large extent on the Trust's success in resolving claims under Option 2.

\section{F. Establishment of a Claims Facility}

The trustees of the Dalkon Shield Claimants Trust decided to establish an in-house facility to handle all aspects (except investment) of claims resolution. The Dalkon Shield Claims Resolution Facility ("the Facility") occupies 20,000 square feet of office space in downtown Richmond, Virginia, and is administered by a professional staff hired by the Trust. Michael Sheppard, a former Clerk of the United States Bankruptcy Court, previously responsible for maintaining Dalkon Shield files during the bankruptcy proceedings, is the Facility's director. The Facility currently has a staff of 280 permanent employees, including 105 in claims evaluation, 74 in operations, 33 in personal contacts, 18 in the legal department, and others in data processing, accounting, and personnel.

The Facility staff is responsible for distributing information and application materials to claimants, receiving, reviewing, and processing claim files, and determining the appropriate payment under the payment guidelines established by the Trust. In addition to its claims processing function, the Facility maintains toll-free telephone lines and a staff of claims representatives. The rules governing the Facility require it to provide each claimant with a "trust contact," who will be responsible for assisting the 
claimant in submitting a claim, answering questions about the claim process, and directing claimants to legal or medical advice and to other counseling. ${ }^{86}$ Actual delivery of payments is performed by a bank under contract with the Trust.

\section{G. The Dalkon Shield Solution-An Evaluation}

The Robins bankruptcy and the eventual establishment of the Dalkon Shield Claimants Trust illustrate the advantages of an aggregate resolution of mass tort claims. The actions taken in the bankruptcy proceeding enabled Robins to achieve the comprehensive resolution of all claims-both present and future-sought by all defendants involved in mass tort controversies. Litigation that had burdened Robins and the Courts for nearly fifteen years at the time the bankruptcy action was filed has, for the most part, been put to rest. A large percentage of the plaintiffs will receive compensation promptly, and the courts and parties will avoid the protracted and costly process of litigating thousands of individual cases.

The Dalkon Shield Claims Resolution Facility illustrates the spectrum of procedures that might be used in distributing funds to a mass of claimants after the settlement of a mass tort controversy. The experience of the Dalkon Shield claims resolution plan is thus likely to play an important role in the development of future mass tort compensation schemes. The following discussion addresses some of the advantages and disadvantages of the Dalkon Shield mechanism based on the experience of the Trust to date.

1. Evaluation of the Dalkon Shield Claims Resolution Mechanism. As noted above, the claims resolution facility established for the Dalkon Shield Claimants Trust illustrates the spectrum of mechanisms available for distributing funds. The Option 1 procedure offers a simple, fixed payment schedule that does not take into account in any respect the facts of a particular claim. The Option 2 procedure involves a slightly more complicated payment schedule that will offer some variation in payment depending on the type and degree of injury. Option 3 offers a range of procedures, each of which involves an individualized examination of the claim. Option 1 is of course the least expensive procedure to administer while Option 3 is likely to be the most costly. Option 1 will provide compensation quickly, while resolution of a claim under Option 3 is likely to take significantly more time.

This multi-tiered approach is appealing. The critics' concerns about the dehumanization of an administrative compensation scheme should be minimized by the ability to select from among several approaches and the plaintiffs' availability of the litigation-type approach in Option 3. Presumably, because each individual plaintiff can select the approach most appropriate to his or her particular situation, the possibility that relatively strong claims will be underpaid and relatively weak claims overpaid will be minimized. If this

86. Disclosure Statement Annex 4, at CRF-5 (cited in note 52). 
presumption is borne out, it should effectively answer the critics' charge that a mass resolution procedure is inherently unfair because it inevitably averages settlement values. Moreover, the availability of the Option 1 quick payment should help minimize administrative costs. One difficulty in developing an effective mechanism for delivering compensation in the mass tort context is achieving the appropriate balance between the need to scrutinize individual claims for legitimacy and value and the need to minimize administrative expenses. By allowing claimants themselves to select the Option 1 payment, the Trust has in effect eliminated the costs associated with identifying the weak or illegitimate claims.

On the other hand, allowing the individual claimant to select the appropriate resolution option could lead to undesirable results. There is a danger that the less educated, less aggressive, and more impecunious claimants will select the quick and easy Option 1 payment scheme, even if they may have a more valuable claim. However, a preliminary analysis of the 113,000 individuals who have already received a settlement under Option 1 indicates that this undesirable result has not occurred. A comparison of the claims paid against the comprehensive claim database compiled during the bankruptcy proceedings reveals that less than 1 percent of the claims settled under Option 1 demonstrate characteristics associated with a more valuable claim.

Allowing the individual claimants to select the claim resolution option also has certain risks for the Trust. Because the Trust cannot control the volume of claims processed under each option, the Trust will be unable to project the administrative costs of settling the outstanding claims with a high degree of certainty.

2. Implications for Future Mass Tort Controversies. Because the Dalkon Shield Trust has been distributing funds only recently, there is not as yet sufficient information to evaluate the success of the claims resolution procedures. At this preliminary stage, however, it appears that this multi-tiered approach might provide an optimal mechanism for resolving individual claims in a mass tort settlement. The de minimis payment offered under Option 1 disposed of 40 percent of the claims in a few months' time. The claimants would never be able to achieve such results under the traditional tort approach. ${ }^{87}$ The critical test of the Dalkon Shield claims resolution method is the implementation of Option 2. In order to operate successfully, the Trust must resolve the bulk of the remaining claims under Option 2. Option 2 is intended to provide the means for resolving moderately valuable claims with a minimum of administrative costs. If the Trust is able to attract large numbers of claimants

87. Some might argue that this achevement is of dubious value because the type of caims settled under Option 1 would not ordinarily arise in the traditional tort context. The procedural requirements and economic costs associated with the tort system create certain barriers to access that would discourage the filing of weak or uncertain claims. 
to Option 2 while, at the same time, retaining sufficient funds to satisfy the more difficult and more costly Option 3 claims, the mechanism will be a success. 